\title{
Bacterial diversity of Gymnodinium catenatum and its relationship to dinoflagellate toxicity
}

\author{
David H. Green ${ }^{1, *}$, Mark C. Hart ${ }^{1}$, Susan I. Blackburn' ${ }^{2}$, Christopher J. S. Bolch ${ }^{3}$ \\ ${ }^{1}$ Scottish Association for Marine Science, Dunstaffnage Marine Laboratory, Oban PA37 1QA, UK \\ ${ }^{2}$ CSIRO Marine and Atmospheric Research, Hobart, Tasmania 7000, Australia \\ ${ }^{3}$ National Centre for Marine Conservation and Resource Sustainability, Australian Maritime College, \\ University of Tasmania, Locked Bag 1370, Launceston, Tasmania 7250, Australia
}

\begin{abstract}
Gymnodinium catenatum Graham (Dinophyceae) is one of several marine dinoflagellates responsible for outbreaks of paralytic shellfish poisoning (PSP), a problem that is considered to be increasing globally. Bacteria associated with these dinoflagellates have been implicated as potentially involved with the production of PSP toxins, and this study sought to identify whether there was a link between the toxicity of $G$. catenatum laboratory cultures and the diversity of the associated bacterial community. Bacterial 16S rRNA gene clone libraries were constructed and sequenced to identify the bacterial diversity of $7 \mathrm{G}$. catenatum cultures of 2 contrasting toxicity levels. Phylogenetic membership and community structure were examined, including the use of UniFrac, $F_{\mathrm{ST}}$ and LIBCOMPARE. No statistically significant differences that distinguished between toxic and low-toxicity G. catenatum cultures were identified in the bacterial community membership or structure. Furthermore, no coherent phylogenetic group of bacteria was observed to co-associate with culture toxicity. However, observed variation in bacterial diversity and community structure was based on the geographic origin of the $G$. catenatum cultures. Overall, while it was not possible to identify an apparent link between bacterial diversity and the toxicity of $G$. catenatum cultures, we suggest, on the balance of this study and others, that bacterial influence on PSP toxin production may be indirect and mediated by the effects of the bacterial community on algal physiology.
\end{abstract}

KEY WORDS: Gymnodinium catenatum - Paralytic shellfish toxins · 16S rDNA bacterial diversity • Algae-associated bacteria

Resale or republication not permitted without written consent of the publisher

\section{INTRODUCTION}

It has been speculated for several decades that bacteria associated with toxic marine dinoflagellates, such as Gymnodinium catenatum Graham, can play a role in the production of phycotoxins, such as the paralytic shellfish toxins (PSTs) (Doucette et al. 1998, Kodama et al. 2006). The question of whether bacteria have a direct role in paralytic shellfish poisoning (PSP), or produce PSTs autonomously, has been examined by a number of researchers, but the evidence remains inconclusive (Kodama et al. 1990, Levasseur et al. 1996, Gallacher et al. 1997, Smith et al. 2002,
Azanza et al. 2006). Several hypotheses that propose a role for bacteria in PST production have been put forth. One of the main hypotheses is that bacteria could contribute to PSP toxicity through the direct accumulation of autonomously produced bacterial PSTs by shellfish or other organisms in the absence of the dinoflagellate. There is no doubt that many cyanobacteria can autonomously produce PST compounds, and a plausible biosynthetic pathway has been recently described (Kellmann et al. 2008), but the evidence for PST production by other heterotrophic bacterial groups is weaker. While a number of bacteria have been reported to produce toxins having 
chromatographic and biological activity similar to that of PST compounds (Kodama et al. 1988, Gallacher et al. 1997, Smith et al. 2002), several studies have demonstrated that this activity can be attributed to compounds structurally unrelated to PSTs (Sato \& Shimizu 1998, Baker et al. 2003, Martins et al. 2003). Alternatively, bacteria may be directly involved in dinoflagellate PST biosynthesis by supplying precursor compounds or synthesizing key intermediates in the biosynthetic pathway (Gallacher \& Smith 1999). What these compounds might be has yet to be determined. Another possibility is that instead of directly affecting PST biosynthesis, the bacteria could act on the released toxins, either converting saxitoxin congeners to forms with more or less toxicity (Smith et al. 2002), or, as has been demonstrated, reducing the total toxin load by direct elimination of them (Smith et al. 2001, Donovan et al. 2009).

If bacteria do not have a direct role in toxicity, it may be that a combination of effects rather than a direct contribution to toxin synthesis is involved. A number of studies have tested this by using chemical washing and/or antibiotic treatment to eliminate bacteria from toxic dinoflagellate cultures. After treatment, some cultures show increased toxicity (Hold et al. 2001a, Wang et al. 2004, Ho et al. 2006), whereas other studies report decreased culture toxicity following bacterial removal (Doucette \& Powell 1998, Uribe \& Espejo 2003, Ho et al. 2006, Martins 2007). These studies clearly demonstrate that the composition of the bacterial community can influence the PST content of dinoflagellate cells, but the mechanism remains completely unknown. While changes in PST content may still be due to the direct involvement of specific bacteria in PST production, it is conceivable that PST production by the dinoflagellate may be an indirect effect of bacteria acting on algal cellular physiology, by mechanisms such as nutrient competi- tion (Ho et al. 2006) or the production of inhibitory or stimulatory compounds (Sawayama et al. 1993, Lee et al. 2000).

This study and that of Green et al. (2004) utilised a unique collection of laboratory Gymnodinium catenatum cultures that display significant differences in their cellular PST content. Ordinarily, G. catenatum cultures established from vegetative cells collected from field material (CAWD101, GC21V, GCDE08 and YC499B15; Table 1) produce a diverse suite of PST compounds typically in excess of 20 to $50 \mathrm{fmol}$ PST cell $^{-1}$ (Oshima et al. 1993a, Negri et al. 2007). However, some laboratory cultures derived from washed single sexual resting cysts (GCHU11, GCJP01 and GCTRA14; Table 1) produce an order of magnitude less toxin per cell and a restricted range of PST compounds (Negri et al. 2007). From these observations it was speculated that the laboratory isolation process of vigorous washing and ultra-sonication of single cysts prior to germination may have reduced the bacterial community diversity and directly or indirectly inhibited resumption of PST production after germination (Bolch et al. 2001).

In this study, we examined the hypothesis that the low-toxicity and reduced toxin profile of cyst-germinated Gymnodinium catenatum cultures was associated with a reduction in bacterial community diversity, or that other differences in the bacterial community composition might explain the observed differences in cellular toxicity of $G$. catenatum cultures. We compared the total bacterial diversity of 4 toxic and 3 lowtoxicity G. catenatum cultures identified using 16S rRNA gene clone libraries, and then analysed the total (clone and cultivable) identified bacterial diversity by using several phylogenetic diversity approaches, including the web-based analytical tool UniFrac (Lozupone \& Knight 2005), $F_{\mathrm{ST}}$ (Martin 2002), and LIBCOMPARE (Wang et al. 2007).

Table 1. Origin and toxicity of the Gymnodinium catenatum cultures examined in this study. na: data not available. bd: below detection limit. STX: saxitoxin

\begin{tabular}{|c|c|c|c|c|}
\hline Strain & $\begin{array}{c}\text { Toxicity } \\
\left(\text { (fmol STX cell }^{-1}\right)\end{array}$ & Isolation source & $\begin{array}{l}\text { Isolation } \\
\text { date }\end{array}$ & Culture collection \\
\hline \multicolumn{5}{|c|}{ Typical toxicity (cultures isolated from vegetative cells) } \\
\hline CAWD101 & na & Kaitaia coast (New Zealand) & 2000 & Cawthron Institute (NZ) \\
\hline GC21V & 244 & Ria de Vigo (Spain) & 1986 & $\mathrm{CCMP}^{\mathrm{a}}(\mathrm{USA})$ \\
\hline GCDE08 & 189 & Derwent Estuary, Tasmania (Australia) & 1987 & ANACC (Australia) ${ }^{\mathrm{b}}$ \\
\hline YC499B15 & 316 & Yellow Sea (Korea) & 1998 & T. G. Park (Korea) \\
\hline \multicolumn{5}{|c|}{ Low toxicity (cultures isolated from sexual resting cysts) } \\
\hline GCHU11 & 4 & Huon Estuary, Tasmania (Australia) & 1988 & ANACC (Australia) \\
\hline GCJP01 & bd & Seto Inland Sea (Japan) & 1985 & ANACC (Australia) \\
\hline GCTRA14 & 3 & Spring Bay, Tasmania (Australia) & 1993 & ANACC (Australia) \\
\hline
\end{tabular}




\section{MATERIALS AND METHODS}

Gymnodinium catenatum culture isolation. Cultures CAWD101, GC21V, GCDE08 and YC499B15 (Table 1) were generated from single vegetative cells or single chains of vegetative cells isolated from field material using micropipetting techniques. The stringency of washing used to remove contaminating material and bacteria is not known and can vary from person to person. Cultures GCHU11 and GCTRA14 (Table 1) were generated from single sexual resting cysts collected from field material. The cysts were washed vigorously using ultra-sonication and repeatedly washed in sterile growth medium to separate them from contaminating material, prior to germination. The isolation methodology used to generate culture GCJP01 is less well documented but, again, was based on germination of a single sexual resting cyst. Culture GCJP01 was subsequently re-isolated by single-cell micropipetting upon receipt by the Australian National Algae Culture Collection.

Algal culture. The Gymnodinium catenatum strains used in this study (Table 1) were grown at $18^{\circ} \mathrm{C}$ in $25 \mathrm{~cm}^{2}$ tissue culture flasks (Nunc) in F/2+Se medium supplemented with L1 trace metals (Guillard \& Hargraves 1993) at a photon flux density of $70 \mu \mathrm{mol}$ photosynthetically active radiation (PAR) $\mathrm{m}^{-2} \mathrm{~s}^{-1}$ supplied by cool-white fluorescent lighting (Phillips) with a photoperiod of 12:12 h (light:dark). All cultures were handled aseptically to prevent bacterial contamination and cross-contamination between cultures.

16S rRNA gene clone library construction and ARDRA analysis. Bacterial cells were harvested by pelleting $1 \mathrm{ml}$ of late exponential phase algal cells at $12000 \times g$ for $30 s$, and the cell pellet was stored at $-80^{\circ} \mathrm{C}$ until DNA extraction. At the same time, Gymnodinium catenatum cells from each culture were harvested by centrifugation $(2000 \times g$ for $5 \mathrm{~min})$, and 10 fold serial dilutions of the suspended cells plated on dilute marine agar. The resultant cultivable isolates were identified by $16 \mathrm{~S}$ rRNA gene sequencing. Full details of the isolation procedure and analysis have been reported previously (Green et al. 2004). Bacterial genomic DNA was extracted using a cetyltrimethylammonium bromide purification method (Ausubel et al. 1999) amended as follows: the cell pellet was suspended in $100 \mathrm{mM}$ Tris- $\mathrm{HCl}(\mathrm{pH} 8.0), 150 \mathrm{mM} \mathrm{NaCl}$ and $10 \mathrm{mM}$ EDTA, and lysozyme (5 $\mathrm{mg} \mathrm{ml}^{-1}$ final concentration) was then added and incubated at $37^{\circ} \mathrm{C}$ for $30 \mathrm{~min}$.

Amplified ribosomal DNA restriction analysis (ARDRA) was carried out essentially as described by Moyer (2001). The polymerase chain reaction (PCR) was used to amplify the small subunit rRNA gene (16S rDNA) from the chromosomal DNA using primers $27 \mathrm{~F}$ and 1492R (Weisburg et al. 1991). PCR was carried out on a PTC200 DNA Engine Thermocycler (MJ Research) and used $1 \mathrm{U}$ of Taq polymerase (ABgene) in a $50 \mathrm{\mu l}$ reaction containing a final concentration of $1.8 \mathrm{mM} \mathrm{Mg}^{2+}, 20 \mathrm{mM} \mathrm{NH}_{4} \mathrm{SO}_{4}, 75 \mathrm{mM}$ Tris- $\mathrm{HCl}(\mathrm{pH}$ 8.8) and $0.01 \%$ Tween-20, and $0.5 \mu \mathrm{M}$ of each primer. Cycling parameters were $94^{\circ} \mathrm{C}$ for $2 \mathrm{~min} ; 20$ cycles of $55^{\circ} \mathrm{C}$ for $30 \mathrm{~s}, 72^{\circ} \mathrm{C}$ for $3 \mathrm{~min}$ and $94^{\circ} \mathrm{C}$ for $10 \mathrm{~s}$; followed by $72^{\circ} \mathrm{C}$ for $10 \mathrm{~min}$. For each algal strain, the amplified bacterial 16S rDNA from 3 independent PCR reactions were pooled and purified with Montage-PCR filters (Millipore). Pooled 16S rDNA (25 ng) was then ligated into $25 \mathrm{ng}$ pGEM-T Easy (Promega) and transformed into chemically competent Escherichia coli XL1-Blue (Stratagene). A total of 96 clones from each clone library were picked at random using sterile wooden toothpicks, and each clone amplified in a single $50 \mu \mathrm{l}$ PCR reaction containing primers ARD-F and ARD-R that immediately flank the pGEM-T Easy cloning site (Green et al. 2004) at a final concentration of $0.1 \mu \mathrm{M}$ (all other reaction components were as listed above), and cycled as follows: $94^{\circ} \mathrm{C}$ for $2 \mathrm{~min} ; 30$ cycles of $60^{\circ} \mathrm{C}$ for $30 \mathrm{~s}, 72^{\circ} \mathrm{C}$ for $1.5 \mathrm{~min}$ and $94^{\circ} \mathrm{C}$ for $10 \mathrm{~s}$; followed by $72^{\circ} \mathrm{C}$ for $10 \mathrm{~min}$. From each PCR, $15 \mu \mathrm{l}$ of the amplified DNA was restricted by double-digestion using $10 \mathrm{U}$ Rsa I and 10 U Msp I and Buffer B as supplied by the manufacturer (Promega) in a final reaction volume of $30 \mu \mathrm{l}$. Following incubation $\left(18 \mathrm{~h}\right.$ at $\left.37^{\circ} \mathrm{C}\right)$, the restricted DNA was electrophoresed through $2.5 \%$ MetaPhor agarose (BioWhittaker) prepared in $1 \times$ TrisBorate-EDTA (TBE) at a voltage of $5 \mathrm{~V} \mathrm{~cm}^{-1}$ for $4 \mathrm{~h}$. DNA was visualised by ethidium bromide staining and UV-transillumination. The abundance of each ARDRA pattern (operational taxonomic group; OTU) was assessed and scored following visual inspection of the ARDRA patterns.

A plasmid DNA representative of each OTU was prepared using NucleoSpin Plasmid kit (MachereyNagel, ABgene), and sequenced in the forward direction using the 27F primer (Weisburg, et al. 1991) and 'Big-Dye' terminator chemistry version 1.1 (Applied Bio-systems) according to standard protocols. Sequence reactions were electrophoresed on an ABI 377 DNA sequencer, and resulting sequences were aligned and manually checked for consistent basecalling using Sequence Navigator (Version 1.0.1, Applied Biosystems).

Phylogenetic and statistical analysis. Genetic identity of each 16S rRNA gene sequence was determined using Ribosomal Database Project II (RDP II) Sequence Match (Cole et al. 2005). Genetic identity was in most instances assigned to the closest taxonomically described bacterial sequence in the RDP II. Putative chimeric 16S rDNA clones were identified following submission to the CHIMERA-CHECK facility of the RDP II (Cole et al. 2005). 
For phylogenetic inference, sequences were aligned with the NAST automatic aligner (http://greengenes. lbl.gov) (DeSantis et al. 2006) and imported into the ARB software suite using the ARB parsimony tool (Ludwig et al. 2004). The alignment was refined, and ambiguous positions in the alignment were masked from the analysis. Phylogenetic inference was based on distance matrices and neighbour-joining (NJ) (Saitou \& Nei 1987) of the masked alignment, as implemented in ARB. Bootstrap resampling was used to test support for the inferred tree topology. OTUs were annotated by the Gymnodinium catenatum culture from which they originated followed by an alphabetic suffix.

Bacterial species richness of the clone libraries was estimated by the Chao-1 non-parametric estimator (http://www2.biology.ualberta.ca/jbrzusto/rarefact.php) (Colwell \& Coddington 1994). The Shannon diversity index was calculated using the MOTHUR software suite (Schloss et al. 2009). To examine if there was a consistent pattern in presence/absence of phylotypes or bacterial diversity correlated with these 2 groups, we divided the 7 cultures into 2 groups on the basis of their reported culture toxicity (Table 1): cultures with typical levels of PST (GC21V, GCDE08, YC499B15 and CAWD101) and those with low to undetectable PST (GCHU11, GCJP01 and GCTRA14). The first hypothesis tested was whether the abundance of one taxonomic group was over- or underrepresented within either group. The OTU clone abundance data were used to derive an overall estimate of the abundance of each taxon in the cultures and OTU clone abundance of Alphaproteobacteria and Gammaproteobacteria, and Bacteroidetes was examined using a single factor analysis of variance (ANOVA). The second hypothesis tested was whether there was a difference in the total phylogenetic diversity of the 2 culture sets. To do this, we compiled both OTU (this study) and cultivable (Green et al. 2004) data and examined the mean species richness of the main taxonomic groups (Alphaproteobacteria, Gammaproteobacteria and Bacteroidetes) in the 2 culture sets. Pearson rank correlation was used to examine whether there was a relationship between Gymnodinium catenatum culture toxicity ( $\mathrm{n}=$ 6; Table 1) and OTU or total species richness (Table 2).

LIBCOMPARE (Wang et al. 2007) was used to identify whether specific taxonomic groups were significantly over- or underrepresented in pooled populations according to the following groups: (1) Gymnodinium catenatum cultures of normal or low toxin content (as described above); (2) cultures isolated from the Southern (CAWD101, GCHU11, GCDE08, GCTRA14) or Northern hemisphere (GCJP01, YC499B15, GC21V); (3) the 2 rDNA-ITS genotypes of the G. catenatum strains (C-gene: GC21V and YC499B15; versus T-gene: Australian-New Zealand strains and GCJP01) (Bolch \& de Salas 2007); or (4) cultures isolated during the 1980s
Table 2. Bacterial species richness of Gymnodinium catenatum cultures. Operational taxonomic units (OTUs) were identified by amplified ribosomal DNA restriction analysis (ARDRA), and Chao-1 shows the estimated phylotype richness $( \pm 95 \%$ confidence intervals $)$ of each clone library. Shannon diversity index $\left(H^{\prime}\right)$ was calculated from the number of unique OTUs identified in each $G$. catenatum culture. Data for the number of cultivable strains came from Green et al. (2004) and this study

\begin{tabular}{|c|c|c|c|c|c|}
\hline \multirow{2}{*}{$\begin{array}{l}\text { G. catenatum } \\
\text { culture }\end{array}$} & \multicolumn{3}{|c|}{- OTUs } & \multirow{2}{*}{$\begin{array}{c}\text { Cultivable } \\
\text { strains }\end{array}$} & \multirow[t]{2}{*}{ Total } \\
\hline & No. & Chao-1 & $H^{\prime}$ & & \\
\hline \multicolumn{6}{|c|}{ Typical toxicity } \\
\hline CAWD101 & 12 & $17 \pm 5$ & 2.10 & 11 & 15 \\
\hline GC21V & 16 & $34 \pm 15$ & 2.29 & 9 & 19 \\
\hline GCDE08 & 16 & $18 \pm 2$ & 2.14 & 9 & 17 \\
\hline YC499B15 & 18 & $27 \pm 8$ & 2.35 & 11 & 22 \\
\hline \multicolumn{6}{|l|}{ Low toxicity } \\
\hline GCHU11 & 7 & $8 \pm 1$ & 1.38 & 4 & 7 \\
\hline GCJP01 & 16 & $34 \pm 15$ & 2.56 & 12 & 24 \\
\hline GCTRA14 & 13 & $15 \pm 2$ & 2.27 & 6 & 15 \\
\hline
\end{tabular}

(GC21V, GCDE08, GCHU11, GCJP01), or since 1993 (CAWD101, GCTRA14, YC499B15). Unaligned multiple FASTA files comprising each OTU replicated to equal its abundance in its respective clone library were compiled according to the groups listed above and submitted for LIBCOMPARE analysis (Wang et al. 2007) available at the following website (http://rdp.cme. msu.edu/comparison/).

To further examine bacterial community phylogenetic diversity, the UniFrac approach was used (Lozupone \& Knight 2005). Briefly, 2 distance matrix NJ trees based on masked alignments were calculated in ARB, with the first representing total bacterial diversity (cloned and cultivable species) and the second comprising OTU data (clone library data only) annotated according to Gymnodinium catenatum culture origin, culture toxicity and the number of OTUs (weighted only). UniFrac matrices were calculated as the fraction of tree branch length unique to any one $G$. catenatum culture in pairwise comparisons with all other cultures. Differences in the bacterial community between low-toxicity and typical-toxicity cultures (Table 1) were examined and tested for significance $(\alpha=0.05)$ using UniFrac matrices with data weighted for OTU (clone) abundance (normalised) and also with total (clone OTU and cultivable) unweighted bacterial community data (Lozupone \& Knight 2005). Pairwise UniFrac matrices were then subjected to principal coordinates analysis (PCA) using both the weighted OTU data and unweighted total community data.

To test hypotheses that could account for the clustering of bacterial diversity observed with the UniFrac PCA analysis, we generated a UniFrac distance matrix from pairwise comparisons of all 7 Gymnodinium cate- 
natum cultures (weighted OTU data and unweighted total diversity) and subjected these to a Student's $t$-test, testing whether the average genetic distance between communities within pooled population groups was less than the average distance between communities across population groups (L. Dethfusen pers. comm.). A Bonferroni correction was applied for multiple comparisons $(\alpha=0.05)$. The 4 hypothesised clusters tested were those described above for LIBCOMPARE analysis. We next annotated the UniFrac environmental file to partition the dendogram (weighted OTU data only) according to each of these hypothesised clusters and subjected this to the UniFrac significance test and parsimony test (P-test).

To determine whether the pooled Gymnodinium catenatum bacterial communities (according to the above 4 hypothesized clusters) were genetically distinct from one another, we calculated $F_{\mathrm{ST}}$ as a measure of genetic differentiation between the pooled populations. $F_{\mathrm{ST}}$ was calculated as described for $16 \mathrm{~S}$ rRNA gene clone libraries (Martin 2002) and as implemented by Eckburg et al. (2005). To do this, an NJ distance matrix, according to the Olsen model, was calculated in ARB and exported (Ludwig et al. 2004). A PERL script (Eckburg et al. 2005) was used to calculate $F_{\text {ST }}$ for each of the NJ distance matrices, which subsequently estimates the significance of the calculated $F_{\mathrm{ST}}$ by determining an empirical null distribution for $F_{\mathrm{ST}}$, by 1000 random assignments of the clone library sequences to the populations. Where the random $F_{\mathrm{ST}}$ ( $p=0.001$ ) was greater than the calculated $F_{\mathrm{ST}}$, this was indicative of significant differences in the partitioning of genetic diversity between the pooled populations.

DNA sequences from this study have been deposited under the following accession numbers: AY701416 to AY701472, and DQ660886 to DQ660888.

\section{RESULTS}

\section{S rRNA gene clone libraries}

Bacterial small subunit rRNA gene (16S rDNA) clone libraries from each of the Gymnodinium catenatum strains are listed in Table 1. Between 89 and 95 clones of the original 96 clones picked from each of the 7 libraries contained 16S rDNA inserts that were subjected to ARDRA analysis. Following the sequencing of representative clones of each OTU, where 2 or more OTU sequences from the same clone library were $\geq 99.0 \%$ similar to one another, the OTUs were merged and scored as a single OTU. Six clones were identified as putative chimeras and removed from further analysis.
Rarefaction analysis indicated near to saturation coverage of the bacterial diversity of the 7 clone libraries (data not shown). However, the Chao-1 estimator of phylotype richness indicated a potential undersampling of the actual species richness of some cultures (Table 2). A total of 98 OTUs were identified from the 7 Gymnodinium catenatum clone libraries, with 57 OTUs unique to the clone libraries and therefore representing bacteria we had not cultured in our previous work (Green et al. 2004). Of these 57 OTUs, Alphaproteobacteria (39\%) and Bacteroidetes (35\%) were the most frequently identified phylotypes, with the remaining OTUs affiliated with the Gammaproteobacteria (19\%), Planctomycetes (3.5\%) and Verrucomicrobia (3.5\%) (data not shown). An Alphaproteobacteria or Bacteroidetes OTU was typically the most abundant individual OTU in G. catenatum cultures, except in cultures GCJP01 and GC21V, where OTUs affiliated with the OM182 clade (GCJP01_R; $17.5 \%$ ) and Verrucomicrobia (GC21V_A; 26\%), respectively, were the single most abundant OTUs (see Table S1 in the supplement at www.int-res.com/ articles/suppl/a061p073_supp.pdf). Figs. 1 to 3 depict the phylogenetic affiliation of the 57 unique OTUs (see also Table S1) alongside the cultivable bacteria identified by Green et al. (2004) from the same G. catenatum cultures.

\section{Bacterial community composition of Gymnodinium catenatum cultures}

Clone library analysis expanded the bacterial diversity catalogue of the 7 Gymnodinium catenatum cultures from 62 cultivable bacteria to a total of 119 phylotypes (Table 2) spanning 5 phyla. Species richness of the cultures ranged from 7 to 24 (mean $=17$ ) (Table 2). When compared with the cultivable community characterised by Green et al. (2004), data indicated that approximately $52 \%$ of the community associated with $G$. catenatum cultures had been cultivated. Alphaproteobacteria, Gammaproteobacteria and Bacteroidetes were always present in each culture, whereas the identification of Actinobacteria, Verrucomicrobia and Planctomycetes was sporadic and restricted to a total of 2 phylotypes from each phylum.

From a compilation of the total bacterial diversity identified (OTUs and cultivable) across all Gymnodinium catenatum cultures (Fig. 4A), the most frequently encountered bacterial taxa (ca. 44\%) belonged to Alphaproteobacteria, and the majority were affiliated with the Rhodobacteraceae (ca. 61\%). Bacteroidetes phylotypes (ca. $30 \%$ of total diversity) in each $G$. catenatum culture always included affiliates of classes Flavobacteria and Sphingobacteria. Gamma- 


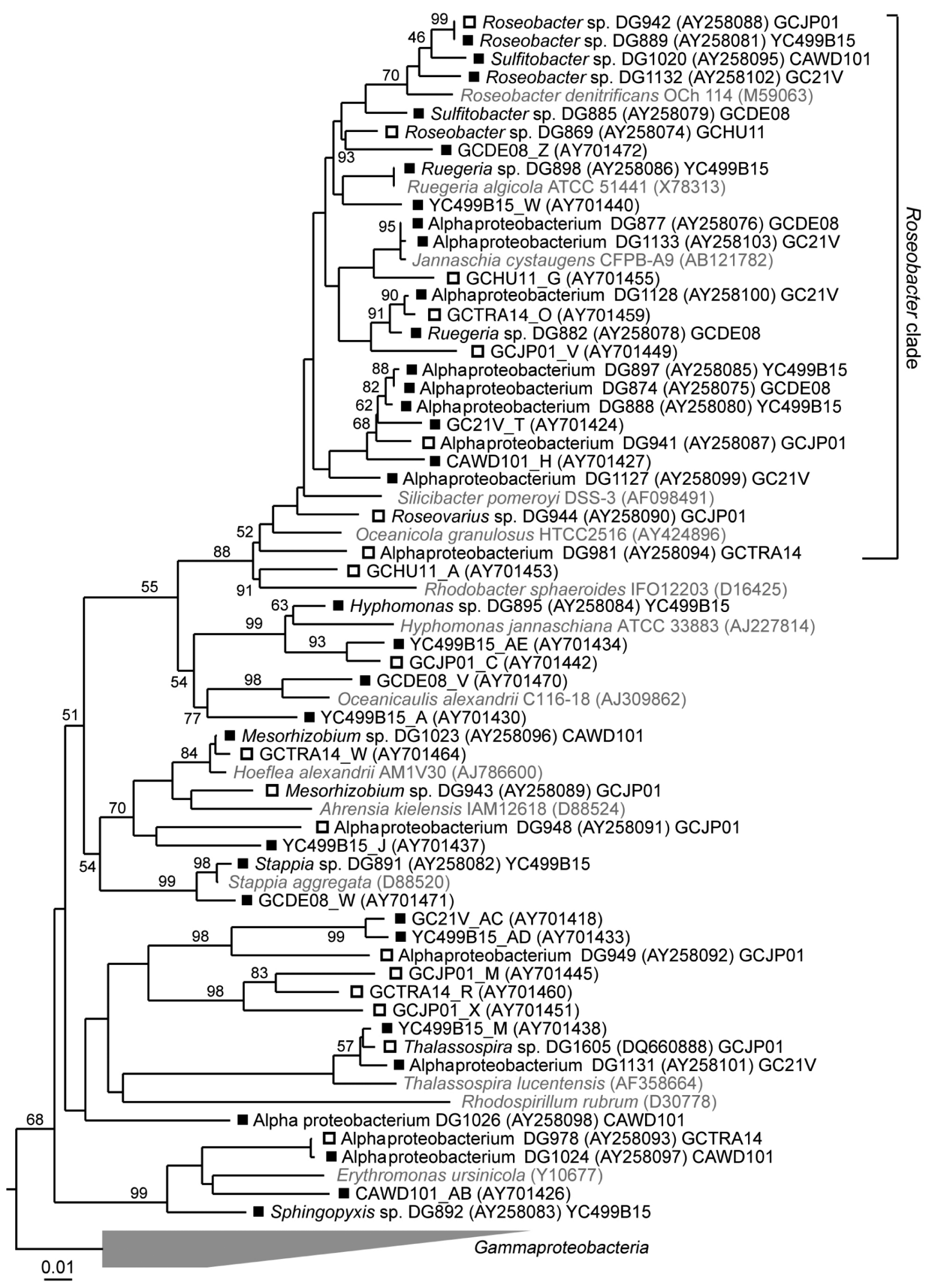

Fig. 1. Neighbour-joining 16S rDNA dendrogram created in ARB software, showing the Alphaproteobacteria diversity identified in Gymnodinium catenatum cultures. Bootstrap support $\geq 50 \%$ for the inferred tree is shown. G. catenatum bacteria are in black typeface, and representative bacteria or clones from GenBank are in grey typeface. Strains from typical and low-toxicity $G$. catenatum cultures are denoted by the symbols $\mathbf{\square}$ and $\square$, respectively. Scale bar shows substitutions per site 


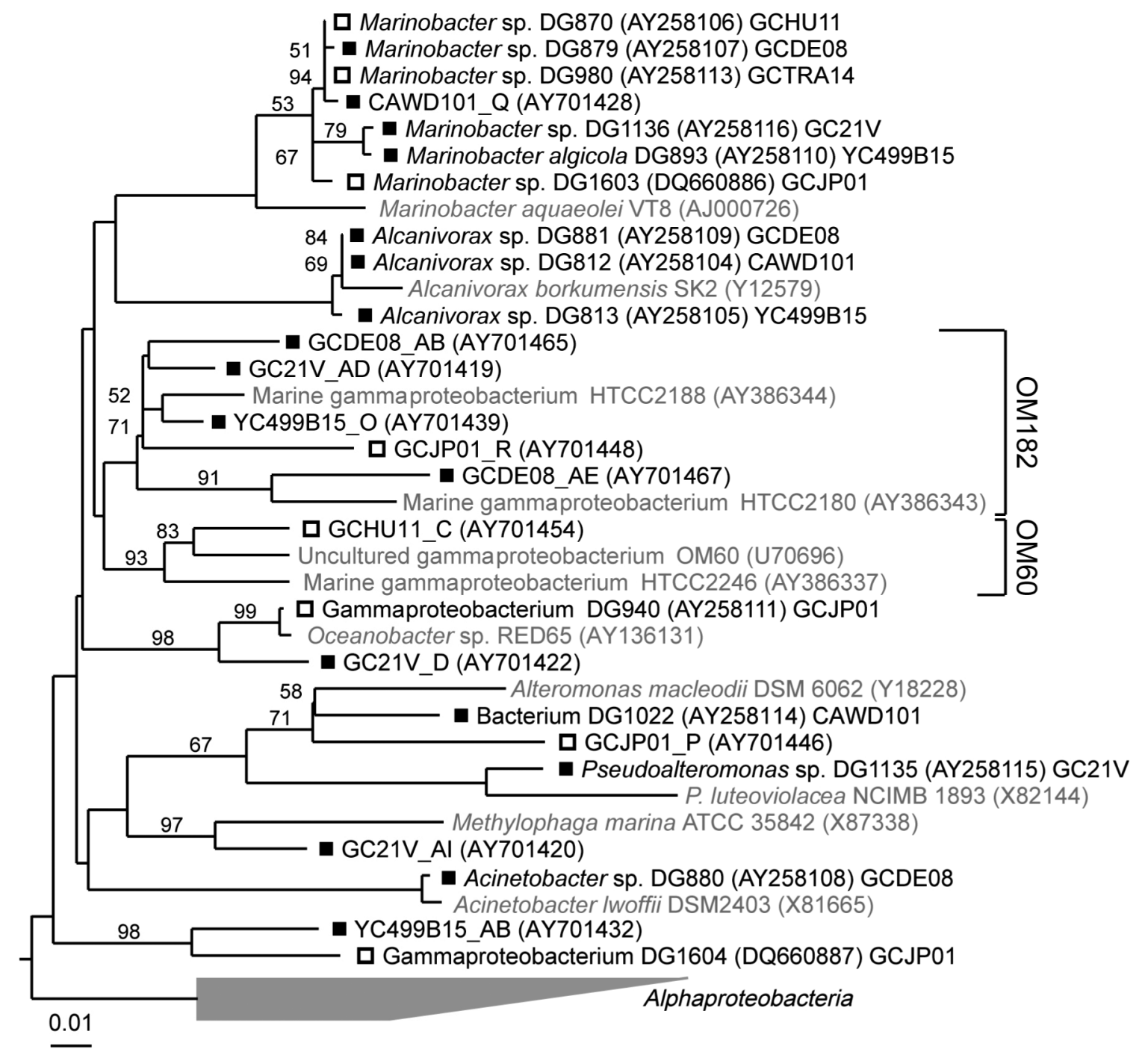

Fig. 2. Neighbour-joining 16S rDNA dendrogram created by ARB software, showing the Gammaproteobacteria diversity identified in Gymnodinium catenatum cultures. G. catenatum bacteria are in black typeface, and representative bacteria or clones from GenBank are in grey typeface. Bootstrap support $\geq 50 \%$ for the inferred tree is shown. Strains from typical and low-toxicity $G$. catenatum cultures are denoted by the symbols $\boldsymbol{\square}$ and $\square$, respectively

proteobacteria comprised ca. $21 \%$ of the total bacterial diversity, while Actinobacteria, Planctomycetes and Verrucomicrobia were identified infrequently, and the species richness of each phyla represented $1.7 \%$ of the total diversity (Fig. 4A).

\section{Bacterial communities of toxic and low-toxicity Gymnodinium catenatum cultures}

The 7 Gymnodinium catenatum cultures examined in this study could be divided into 2 groups on the basis of their reported culture toxicity (Table 1): cultures with typical levels of PST (GC21V, GCDE08,
YC499B15 and CAWD101) and those with low to undetectable PST (GCHU11, GCJP01 and GCTRA14). The bacterial diversity of these 2 groups was examined using statistical methods.

No significant differences were observed in the abundance of clones affiliated with the Alphaproteobacteria, Gammaproteobacteria or Bacteroidetes $\left(F_{1,5} \leq 3.146\right.$, $\mathrm{p} \geq 0.136$ ) between normal and low-toxicity groups of cultures (Fig. 4B). No significant differences in species richness of the main taxonomic groups (Alphaproteobacteria, Gammaproteobacteria and Bacteroidetes) were detected between the normal and low-toxicity groups $\left(F_{1,5}\right.$ $\leq 1.42, \mathrm{p} \geq 0.29$ ) (Fig. $4 \mathrm{C}$ ). While the mean species richness and clone abundance of Roseobacter phylotypes 
appeared lower in low-toxicity cultures, these differences were not significant (species richness $F_{1,5}=2.28$, $\mathrm{p}=0.19$; clone abundance $F_{1,5}=2.32, \mathrm{p}=0.19$ ). Similarly, no significant differences in abundance of Flavobacteria and Sphingobacteria were identified between normal and low-toxicity groups $\left(F_{1,5} \leq 0.19, \mathrm{p} \geq 0.68\right)$.
Pearson rank correlation was used to examine whether there was a relationship between Gymnodinium catenatum culture toxicity $(\mathrm{n}=6$; Table 1 ) and OTU or total species richness (Table 2). While values of OTU species richness and total community species richness were generally lower in the low-toxicity cul-

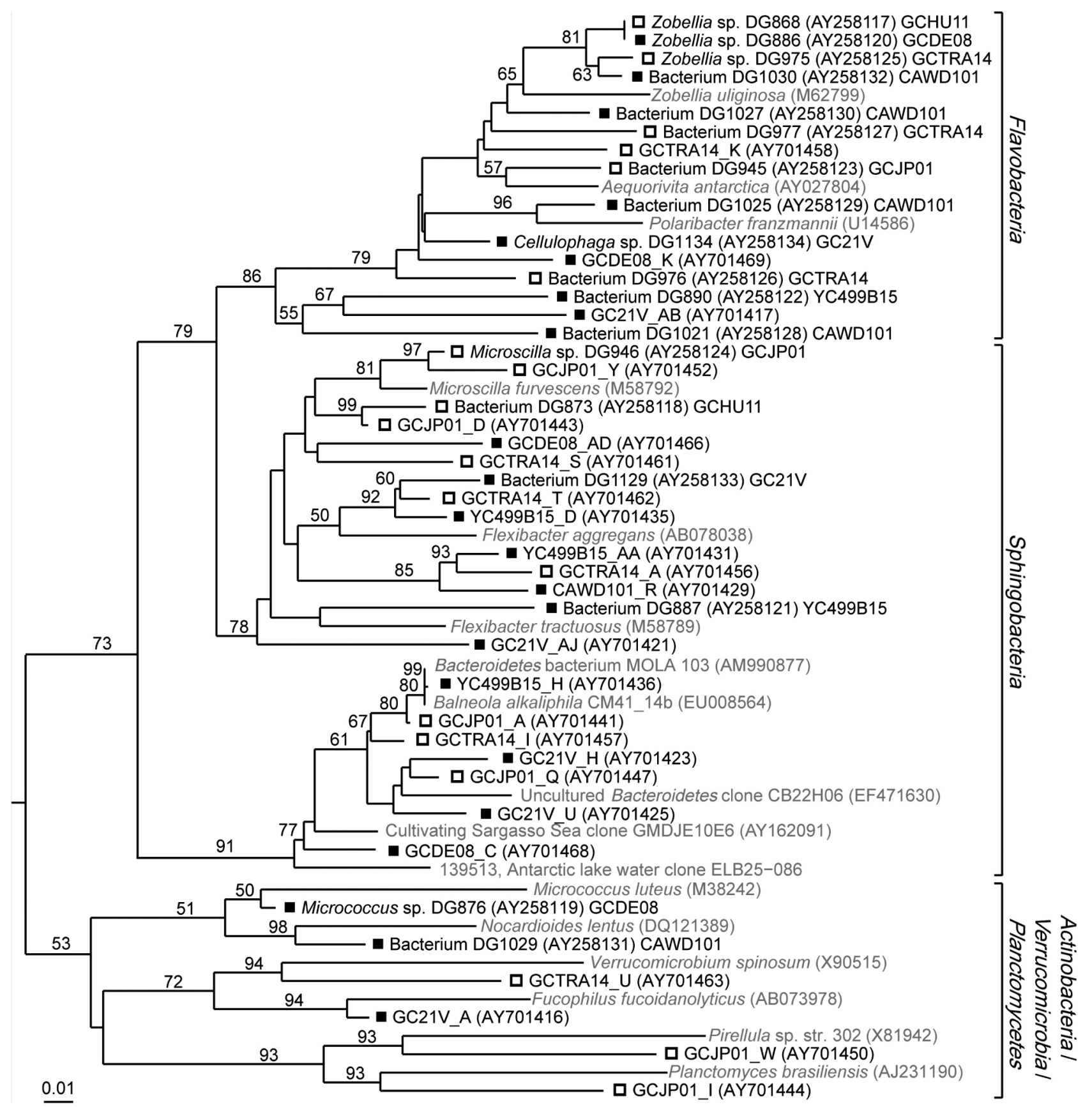

Fig. 3. Neighbour-joining 16S rDNA dendrogram created by ARB software, showing the diversity of Bacteroidetes (Flavobacteria, Sphingobacteria), Actinobacteria, Verrucomicrobia and Planctomycetes identified in Gymnodinium catenatum cultures. Bootstrap support $\geq 50 \%$ for the inferred tree is shown. G. catenatum bacteria are in black typeface, and representative bacteria or clones from GenBank are in grey typeface. Strains from typical and low-toxicity G. catenatum cultures are denoted by the symbols a and $\square$, respectively 
A

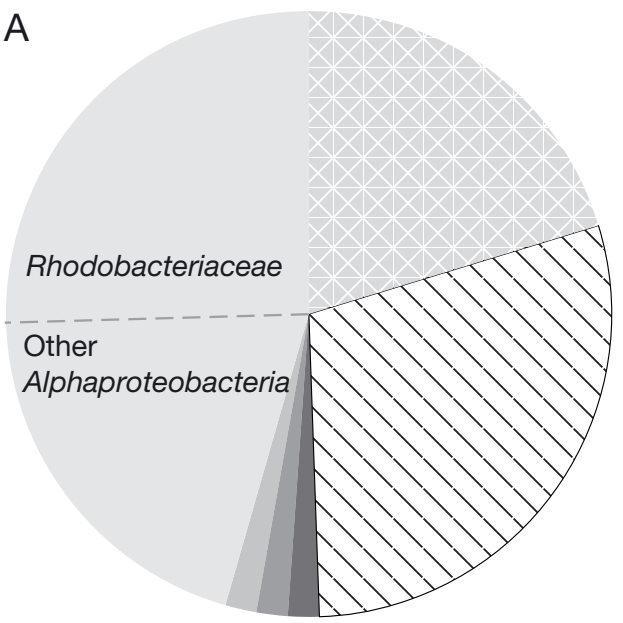

Alphaproteobacteria

Gammaproteobacteria

Bacteroidetes

Verrucomicrobia

Planctomycetes

Actinobacteria

Fig. 4. Bacterial diversity of Gymnodinium catenatum cultures. (A) Percent phylogenetic affiliation of the bacterial diversity of $G$. catenatum (clone libraries and cultivable isolates). The dotted line denotes the percent of alphaproteobacterial diversity affiliated with the family Rhodobacteriaceae and other Alphaproteobacteria. Bar graphs show averaged (B) abundance of operational taxonomic units (OTUs) and (C) species richness (OTU and cultivable) of typical and low-toxicity G. catenatum cultures. Error bars denote 1 standard deviation of the mean
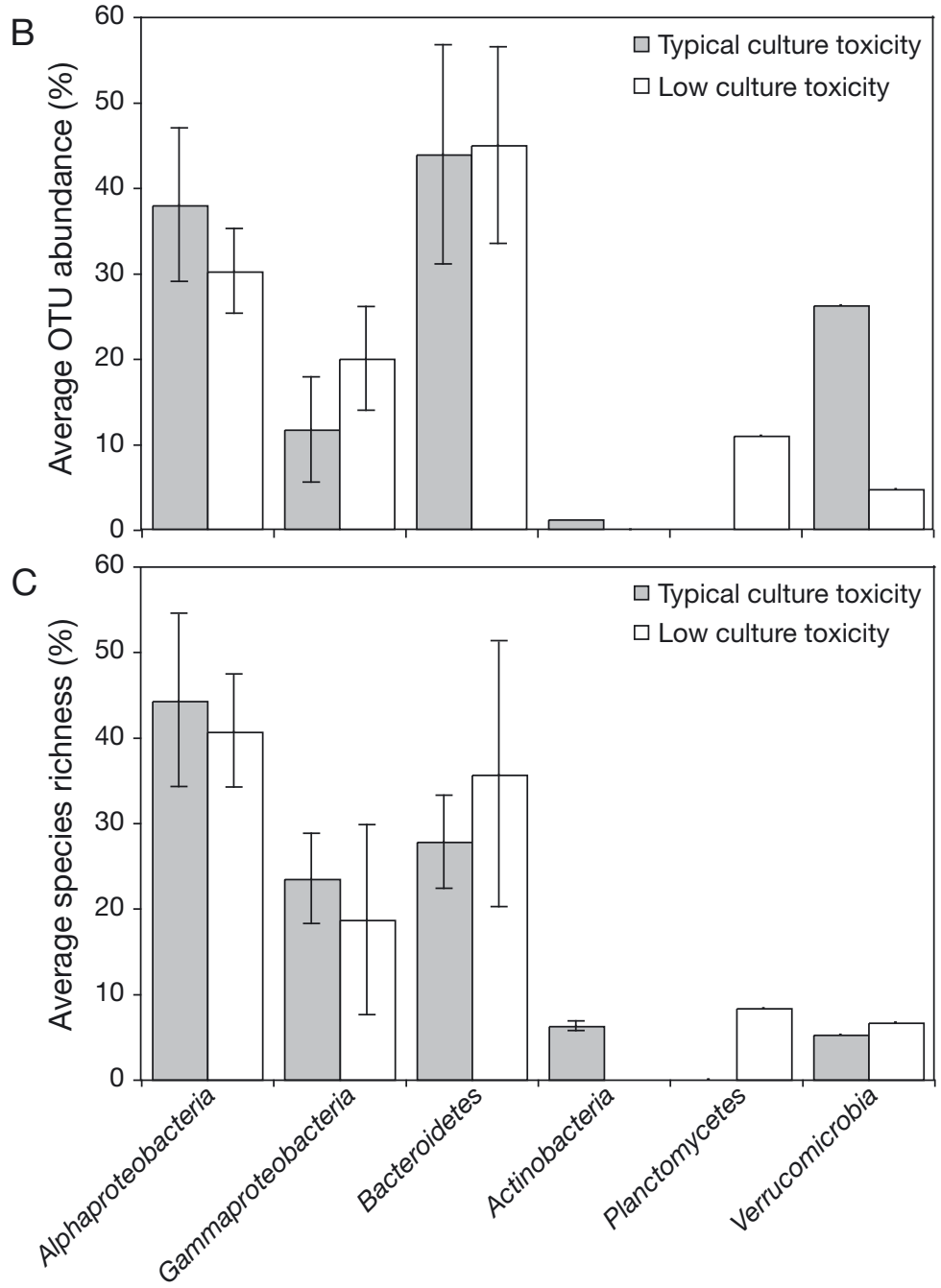

tures, neither trend was significant (OTU $r_{\mathrm{S}}=0.63$; $\mathrm{p}>0.05 ;$ Total $\left.r_{\mathrm{S}}=0.42 ; \mathrm{p}>0.05\right)$.

No consistent patterns were observed in individual phylotype composition between the normal and lowtoxicity groups. Firstly, there was no pattern in the presence or absence of the rare phylotypes (Actinobacteria, Verrucomicrobia and Planctomycetes) (Fig. 3). Secondly, to discern if any phylogenetic cluster correlated with typical or low-toxicity cultures, we annotated each unique 16S rDNA sequence according to culture toxicity (typical or low) and visually examined each phylogenetic tree (Figs. 1 to 3). Within the limits of our phylogenetic tree construction, we could not discern a consistent association of any cluster with normal or low-toxicity cultures. However, LIBCOMPARE analysis indicated the Planctomycetes as overrepresented in the low-toxicity cultures, and Verrucomicrobia as overrepresented in the normal toxicity cultures. As the 2 Planctomycete OTUs occurred in only 1 of the 3 low-toxicity cultures (GCJP01), and the Verrucomi- crobia occurred in 1 normal and 1 lowtoxicity culture, neither represented a consistent difference that distinguished between normal or low-toxicity cultures.

UniFrac analysis detected no significant differences in pairwise comparisons between either the weighted (OTU only; $\mathrm{p}=1.0$ ) or total unweighted (OTU and cultivable; $\mathrm{p}=1.0$ ) bacterial communities associated with typical and low-toxicity cultures. The PCA using UniFrac matrices calculated from weighted OTU data and unweighted total community data are shown in Fig. 5. The total variance explained by the first 2 components of the OTU and total community analyses were 54 and $45 \%$, respectively. It was apparent from this analysis that bacterial communities did not cluster according to culture toxicity when either OTU abundance or total diversity was taken into account (Fig. 5). Instead, the results showed an apparent clustering by the isolation origin of the Gymnodinium catenatum cultures. The bacterial community of strain GC21V from Spain clustered away from all other cultures; the Japanese (GCJP01) and Ko- 

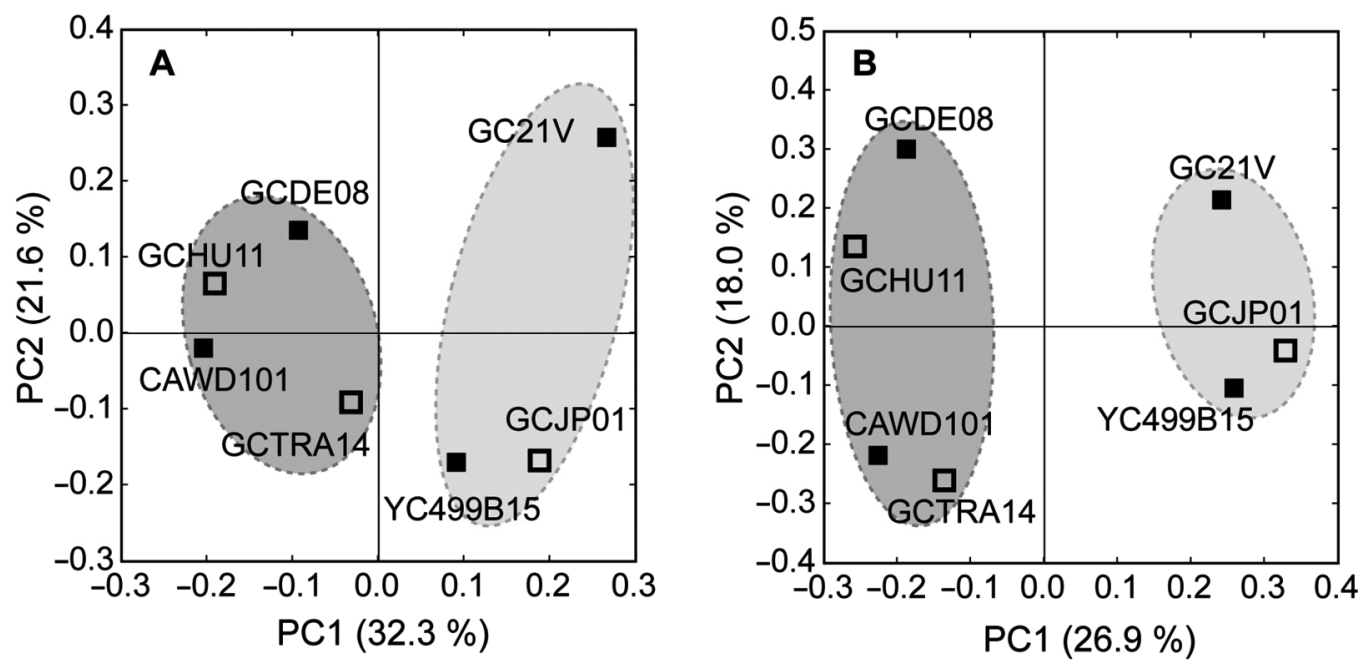

Fig. 5. UniFrac principal coordinates analysis of (A) weighted operational taxonomic units (OTUs) and (B) unweighted total

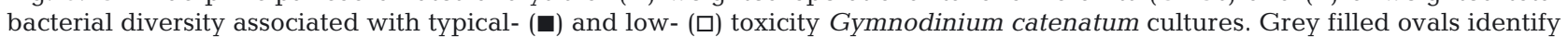
the Southern hemisphere communities (Australia, New Zealand); light grey filled ovals identify the Northern hemisphere communities (Japan, Korea and Spain)

Table 3. Analysis of Gymnodinium catenatum bacterial community clustering probability. Student's $t$-test of the average UniFrac genetic distances within population groups compared to between population groups; *denotes significance $(\alpha=0.05)$ following a Bonferroni correction for multiple comparisons. UniFrac and parsimony (p-test) significance tests of pooled operational taxonomic unit (OTU) data only (weighted for abundance) using UniFrac metrics. $F_{\mathrm{ST}}$ was calculated, where ${ }^{*}$ denotes $F_{\mathrm{ST}}$ was significant $(\mathrm{p}<0.001)$. ns: not significant

\begin{tabular}{|c|c|c|c|c|c|}
\hline Hypothesis & $\begin{array}{r}\text { Stude } \\
\Gamma U \text { diversi }\end{array}$ & $\begin{array}{l}t \text {-test } \\
\text { otal diversity }\end{array}$ & UniFrac & p-test & $F_{\mathrm{ST}}$ \\
\hline Culture toxicity ${ }^{\mathrm{a}}$ & 0.2893 & 0.7015 & $\mathrm{~ns}$ & $\mathrm{~ns}$ & $0.0244^{*}$ \\
\hline Geographic origin & 0.0052 & $<0.0001^{*}$ & $\mathrm{~ns}$ & ns & $0.0328^{*}$ \\
\hline Genotype & 0.0468 & 0.1372 & ns & $\mathrm{ns}$ & $0.0261^{*}$ \\
\hline Isolation date & 0.8587 & 0.8465 & ns & ns & $0.0145^{*}$ \\
\hline
\end{tabular}

rean (YC499B15) cultures clustered close together and are separated from bacterial communities of the Australian-New Zealand strains along the first principal component axis. Analysis of average UniFrac distances within and among bacterial communities within pooled population groups using the Student's $t$-test showed significant support only for the geographic origin hypothesis (unweighted community data only) of the G. catenatum cultures (Table 3).

These 4 hypotheses were also examined for significance using the UniFrac significance and $P$-test, based on pooling individual communities into 2 populations. No significant differences in pairwise comparison for each of the hypotheses examined were observed (Table 3). Subsequent analysis used the $F_{\mathrm{ST}}$ statistic to identify whether there was any significant partitioning of genetic diversity between the pooled populations based on the 4 hypothetical clusters (Table $3)$. Here, $F_{S T}$ indicated that there were significant differences in genetic diversity between the pooled communities for all of the hypothesized clusters. Notably though, the largest $F_{\mathrm{ST}}$ value calculated was for the geographic origin hypothesis, providing a greater measure of support for this hypothesized clustering over the remaining 3 clusters. The combination of significant $F_{\mathrm{ST}}$ values and non-significant $P$-tests indicates that the bacterial communities are composed of unique groups of closely related organisms distributed across the phylogenetic tree (Martin 2002). This is borne out by the examination of the individual trees (Figs. 1 to 3) that show each community has a number of unique phylotypes, but at the broader taxonomic level, all the communities are composed of a very similar taxonomic mix of bacteria (e.g. Roseobacter clade, Marinobacter spp., Flavobacteria).

\section{DISCUSSION}

\section{Bacterial diversity associated with Gymnodinium catenatum}

Overall, 119 bacterial phylotypes were identified from the 7 Gymnodinium catenatum cultures, using a combination of clone libraries (this study) and culture methods (Green et al. 2004). The clone libraries identified $81 \%$ of 
the total species richness identified, and comparison of this clone library data with the cultivable isolates reported previously (Green et al. 2004) demonstrated that $52 \%$ of the OTUs identified were cultivable.

The overall community composition of the Gymnodinium catenatum cultures was similar to that reported by previous studies of dinoflagellates (Alavi et al. 2001, Hold et al. 2001b, Jasti et al. 2005, Pérez-Guzmán et al. 2008). In particular, the broad distribution of phyla is similar to that reported from field samples, where Alphaproteobacteria and, especially, the Roseobacter and Bacteroidetes (Flavobacteria primarily) were the principal taxa associated with dinoflagellate blooms (Fandino et al. 2001, Wichels et al. 2004, Garcés et al. 2007). However, as noted by earlier studies, the overlap between culture studies and field bloom-associated bacteria at the individual phylotype level is often very low (Garcés et al. 2007). In respect to this study, while our culture-derived community structure is potentially skewed by laboratory cultivation, the key point is that it was the process of laboratory cultivation of the 3 lowtoxicity G. catenatum cultures (Table 1 ) that led to their aberrant culture toxicity. And it was this laboratory cultivation artefact that led to our subsequent speculation that a loss or change in the bacterial diversity of these laboratory cultures was in some way the cause of the loss of PST production.

\section{Bacterial community influence on dinoflagellate cell toxicity}

Despite a number of investigations over the past 2 decades examining the relationship of the bacterial community and PST production by dinoflagellates, relatively little is known, and no consistent pattern of association has emerged. One particular hypothesis proposed is that changes in algal cellular toxicity can be the direct or indirect consequence of changes in the bacterial diversity associated with the dinoflagellate. This hypothesis has been corroborated by a number of studies showing that effects on dinoflagellate cellular toxicity do occur following the removal of bacteria (Doucette \& Powell 1998, Ashton et al. 2003a, Wang et al. 2004, Martins 2007). In the case of Gymnodinium catenatum, major changes in per-cell toxicity and the range of PST variants produced in the laboratory appeared to correlate with differences in culture isolation methods (Negri et al. 2007), which we speculated might reduce the bacterial community diversity associated with these cultures.

The loss of community diversity may be manifested as either the loss of specific bacterial types, or a significant change in the overall bacterial community structure, either of which may be essential for a 'nor- mal' level of PST production by the dinoflagellate cell. The first case implies that a specific bacterial type or group will be found only with PST-producing dinoflagellates, and a number of studies have identified individual bacterial strains that appear to have some influence on dinoflagellate toxicity (Kopp et al. 1997, Doucette \& Powell 1998, Plumley et al. 1999, Ashton et al. 2003b). However, studies trying to confirm the existence of specific bacterial types or groups with toxic dinoflagellates only, or studies testing whether there are consistent differences in bacterial community structure associated with toxic and non-toxic species, have proven difficult (Hold et al. 2001b, Jasti et al. 2005). In this study, we used a range of diversity measures and statistical approaches, yet we did not find evidence that low-toxicity cultures harbour a reduced bacterial diversity (Table 2), and we could not identify any over- or underrepresentation of species richness or the abundance of specific taxonomic groups that correlated with culture toxicity (Fig. 4). The lack of correlation with toxicity was also reflected in the comparison of the total identified bacterial diversity of typical versus low-toxicity cultures using the library comparison tool LIBCOMPARE (Wang et al. 2007). Furthermore, the quantitative and qualitative pattern of clustering of bacterial community diversity using the UniFrac PCA analyses (Fig. 5) did not show community structure to be linked with the cellular toxicity of Gymnodinium catenatum cultures. The hypothesis that the G. catenatum culture isolation method might explain the bacterial community structure was not explicity tested as the isolation techniques employed to establish the original G. catenatum cultures analysed here follow the same pattern as culture toxicity (see Table 1). Consequently, as we could not link community structure to culture toxicity, it is therefore also the case that there is no identifiable link between bacterial community structure and $G$. catenatum culture isolation methodology.

Our analysis is consistent with recent studies of other dinoflagellates that have used similar approaches to compare bacterial communities. A comparison of the bacterial communities associated with toxic and nontoxic clones of Alexandrium minutum (= A. lusitanicum) (Palacios et al. 2006, Martins 2007) did identify several bacteria to be specific to each culture. As these studies compared only a single toxic strain with a single non-toxic strain, the authors noted that the differences may instead reflect chance differences in communities rather than being in some way linked to changes in dinoflagellate toxicity. The addition of bacteria from the toxic strain to cultures of the non-toxic strain failed to induce toxin production in non-toxic cultures, suggesting either that the bacterial community is not involved in toxicity, or that simple addition of 
bacteria to the culture was insufficient to induce toxin production in non-toxic A. minutum (Martins 2007).

Overall our study concludes that decreased community complexity, or the presence/absence of a specific phylotype or taxonomic group, cannot be solely responsible for the low toxicity of cyst-derived Gymnodinium catenatum cultures. While bacteria that contribute to dinoflagellate toxicity may indeed exist, our data indicate that they do not comprise a coherent phylogenetic grouping that can be identified as unique to toxin-producing dinoflagellates. However, the molecular analysis used here cannot discern between ecotypes, i.e. strains within a species that have variable phenotypes (Cohan 2002). Thus, we cannot be certain that there may be strains within species groups that cooccur in both toxic and low-toxicity G. catenatum cultures (e.g. Roseobacter and Marinobacter) that influence toxicity in one culture but not in another.

There is ample laboratory culture evidence that removing bacteria from cultures using antibiotic treatment can cause physiological changes and/or alter the PST content of dinoflagellate cells (Hold et al. 2001a, Uribe \& Espejo 2003, Wang et al. 2004, Ho et al. 2006). The mechanisms underpinning these changes are currently unknown. Therefore, it appears likely that changes in the structure and diversity of bacterial communities influence PST production indirectly via their effect on algal physiology, nutrient competition or removal of toxins (Smith et al. 2002, Wang et al. 2004, Ho et al. 2006, Donovan et al. 2009). In the case of Gymnodinium catenatum, the interaction with its bacterial community, or even specific bacterial phylotypes, is essential for survival and culture in the laboratory (Bolch et al. 2004, Subramanian 2007). It has also been demonstrated that different bacterial communities significantly alter basic growth dynamics such as the exponential growth rate, maximum culture yield and length of batch culture growth phases (Subramanian 2007). Thus, the bacterial community, as one type of environmental variable, can potentially influence $G$. catenatum physiology, and this influence may also be reflected by changes in PST biosynthesis.

Other common explanations for the reduction or loss of toxicity typically invoke physiological or selective effects of long-term culture and/or random mutations that reduce or 'switch-off' toxin production. Examples of spontaneous and complete loss of toxicity by dinoflagellate cultures are rare and in all previous cases, the non-toxic strain has, on detailed examination, been determined to be a different species or a regional genotype that is uniformly non-toxic (e.g. United Kingdom ribotypes of Alexandrium tamarense (Higman et al. 2001). However, one credible example reports the complete loss of toxicity by a culture of A. minutum (= A. lusitanicum) during or after its transfer to another laboratory (Martins et al. 2004). While it is impossible to rule out a laboratory labelling error, in this case both the toxic and non-toxic counterpart have been confirmed to possess the same morphological features, identical ribosomal rDNA type (Martins et al. 2004) and similar bacterial communities at a species level, but with several types unique to each culture (Palacios et al. 2006). The authors proposed that spontaneous mutation was an alternative explanation for the observed loss of toxicity, and this suggestion is partially borne out by the work and observations of Cho et al. (2008).

In the case of Gymnodinium catenatum, all known low-toxicity strains continue to produce low concentrations of PST compounds, suggesting that this is a stable characteristic of these aberrant laboratory cultures. Production of the various PST compounds appears to be a heritable trait in Alexandrium (Sako et al. 1992, Ishida et al. 1993) and G. catenatum (Oshima et al. 1993b), indicating that at least some of the biosynthetic pathways for PST synthesis are encoded or controlled by the dinoflagellate genome. The isolation from natural marine sediments, cleaning, manipulation and germination of single G. catenatum cysts in the laboratory typically involves high-energy ultra-sonication. Conceivably this process could damage intracellular structures and/or DNA by thermal stress or free radical production (Milowska \& Gabryelak 2007), resulting in mutations or the mobilisation of genetic elements within the G. catenatum genome that in turn could affect PST biosynthesis. An alternative explanation stems from current evidence that suggests that PST production is 'turned off' or drastically reduced during cyst production by both $A$. tamarense and G. catenatum (Oshima et al. 1992, Bravo et al. 1998), and that the biosynthetic activity of resting cysts is very low (Cembella 1998). Consequently, when resting cysts are germinated in the laboratory, it is possible that PST synthesis is not re-initiated and remains permanently suppressed or 'down-regulated', perhaps owing to some form of gene silencing (Wu-Scharf et al. 2000).

\section{Factors structuring Gymnodinium catenatum bacterial communities}

From our analysis, the bacterial community diversity of Gymnodinium catenatum cultures did not correlate with PST culture content. By contrast, our results indicated that the bacterial diversity structure of the individual cultures was best explained by the geographical origin of the G. catenatum culture. The observed clustering is intriguing given the view that marine microorganisms are considered to be globally distributed (Fenchel \& Finlay 2004). Now, an increasing body of 
evidence is showing that marine microorganisms do have a geographical distribution (Yutin et al. 2007, Fuhrman et al. 2008, Ivars-Martinez et al. 2008). In our case, the communities compared were all drawn from similar environments: temperate surface coastal/shelf waters that support populations of a particular dinoflagellate. Therefore, it would be expected that our data set is unlikely to be strongly confounded by other major community structuring factors (e.g. pelagic versus benthic, coastal versus oceanic, tropical versus temperate), and it is likely to reflect real regional differences among dinoflagellate-associated bacterial communities.

\section{CONCLUSIONS}

Changes in the associated bacterial communities of Gymnodinium catenatum cultures do not show any apparent correlation with culture toxicity, but instead, the geographic origin of the culture isolate was the best explanation for the observed variation in bacterial diversity and community structure among G. catenatum cultures. In light of studies demonstrating that bacteria can influence PST production in Alexandrium species, we anticipate that the bacterial influence on PST biosynthesis is more likely to be indirect and exerted through the community's effect on algal physiology. Therefore, we suggest future studies in this field should examine the interactive effects the bacterial community has on algal physiology and cell biology as a means to address this question.

Acknowledgements. We are grateful for the donation of Gymnodinium catenatum strains by Drs. L. MacKenzie (CAWD101) and T. G. Park (YC499B15). $F_{\mathrm{ST}}$ script and statistical advice were very kindly provided by Dr. L. Dethlefsen. This research was supported by a postdoctoral fellowship from the New Zealand Foundation for Research, Science and Technology to D.H.G.

\section{LITERATURE CITED}

Alavi M, Miller T, Erlandson K, Schneider R, Belas R (2001) Bacterial community associated with Pfiesteria-like dinoflagellate cultures. Environ Microbiol 3:380-396

Ashton M, Rosado W, Govind NS, Tosteson TR (2003a) Culturable and nonculturable bacterial symbionts in the toxic benthic dinoflagellate Ostreopsis lenticularis. Toxicon 42: 419-424

Ashton M, Tosteson T, Tosteson C (2003b) The effect of elevated temperature on the toxicity of the laboratory cultured dinoflagellate Ostreopsis lenticularis (Dinophyceae). Rev Biol Trop 51:1-6

Ausubel FM, Brent R, Kingston RE, Seidman JG, Smith JA, Struhl K (eds) (1999) Short protocols in molecular biology. John Wiley \& Sons, New York, NY

Azanza MPV, Azanza RV, Vargas VMD, Hedreyda CT (2006)
Bacterial endosymbionts of Pyrodinium bahamense var. compressum. Microb Ecol 52:756-764

Baker TR, Doucette GJ, Powell CL, Boyer GL, Plumley FG (2003) GTX $_{4}$ imposters: characterization of fluorescent compounds synthesized by Pseudomonas stutzeri SF/PS and Pseudomonas/Alteromonas PTB-1, symbionts of saxitoxin-producing Alexandrium spp. Toxicon 41:339-347

Bolch CJS, de Salas MF (2007) A review of the molecular evidence for ballast water introduction of the toxic dinoflagellates Gymnodinium catenatum and the Alexandrium tamarensis complex to Australasia. Harmful Algae 6: 465-485

Bolch CJ, Negri AP, Blackburn SI, Green DH (2001) Lifecycle variation in PST content and cell toxicity in PST-producing dinoflagellates. In: Garcés C, Zingone A, Montresor M, Reguera B, Dale B (eds) LIFEHAB: life histories of microalgal species causing harmful blooms. European Commission Directorate General Science, Research and Development, Calvia, p 37-42

Bolch CJS, Vincent B, Blackburn SI, Green DH (2004) Hostsymbiont range of growth stimulating bacteria associated with Gymnodinium catenatum. In: Abstracts of 11th International Conference on Harmful Algal Blooms, 14-19 Nov 2004, Cape Town, p 72

Bravo I, Franco JM, Reyero M (1998) PSP toxin composition of three life cycle stages of Gymnodinium catenatum. In: Reguera B, Blanco J, Fernandez ML, Wyatt T (eds) Harmful microalgae. Xunta de Galicia and IOC of UNESCO, Paris, p 356-358

Cembella AD (1998) Ecophysiology and metabolism of paralytic shellfish toxins in marine microalgae. In: Anderson DM, Cembella AD, Hallegraeff GM (eds) Physiological ecology of harmful algal blooms. Springer-Verlag, Heidelberg, p 55-80

Cho Y, Hiramatsu K, Ogawa M, Omura T, Ishimaru T, Oshima $\mathrm{Y}$ (2008) Non-toxic and toxic subclones obtained from a toxic clonal culture of Alexandrium tamarense (Dinophyceae): toxicity and molecular biological feature. Harmful Algae 7:740-751

Cohan FM (2002) What are bacterial species? Annu Rev Microbiol 56:457-487

Cole JR, Chai B, Farris RJ, Wang Q and others (2005) The ribosomal database project (RDP-II): sequences and tools for high-throughput rRNA analysis. Nucleic Acids Res 33: D294-D296

Colwell RK, Coddington JA (1994) Estimating terrestrial biodiversity through extrapolation. Philos Trans R Soc Lond B Biol Sci 344:101-118

DeSantis TZ, Hugenholtz P, Larsen N, Rojas M and others (2006) Greengenes, a chimera-checked 16S rRNA gene database and workbench compatible with ARB. Appl Environ Microbiol 72:5069-5072

Donovan CJ, Garduno RA, Kalmokoff M, Ku JC, Quilliam MA, Gill TA (2009) Pseudoalteromonas bacteria are capable of degrading paralytic shellfish toxins. Appl Environ Microbiol 75:6919-6923

Doucette GJ, Powell CL (1998) Algal-bacterial interactions: Can they determine the PSP-related toxicity of dinoflagellates. In: Reguera B, Blanco J, Fernandez ML, Wyatt T (eds) Harmful algae. Xunta de Galicia and IOC of UNESCO, Paris, p 406-409

Doucette GJ, Kodama M, Franca S, Gallacher S (1998) Bacterial interactions with harmful algal bloom species: bloom ecology, toxigenesis, and cytology. In: Anderson DM, Cembella AD, Hallegraeff GM (eds) Physiological ecology of harmful algal blooms, Vol G 41. Springer-Verlag, Berlin, p 619-647 
Eckburg PB, Bik EM, Bernstein CN, Purdom E and others (2005) Diversity of the human intestinal microbial flora. Science 308:1635-1638

Fandino LB, Riemann L, Steward GF, Long RA, Azam F (2001) Variations in bacterial community structure during a dinoflagellate bloom analyzed by DGGE and 16S rDNA sequencing. Aquat Microb Ecol 23:119-130

Fenchel T, Finlay BJ (2004) The ubiquity of small species: patterns of local and global diversity. BioScience 54:777-784

Fuhrman JA, Steele JA, Hewson I, Schwalbach MS, Brown MV, Green JL, Brown JH (2008) A latitudinal diversity gradient in planktonic marine bacteria. Proc Natl Acad Sci USA 105:7774-7778

> Gallacher S, Smith EA (1999) Bacteria and paralytic shellfish toxins. Protist 150:245-255

> Gallacher S, Flynn KJ, Franco JM, Brueggemann EE, Hines HB (1997) Evidence for production of paralytic shellfish toxins by bacteria associated with Alexandrium spp. (Dinophyta) in culture. Appl Environ Microbiol 63: 239-245

- Garcés E, Vila M, Reñe A, Alonso-Sáez L and others (2007) Natural bacterioplankton assemblage composition during blooms of Alexandrium spp. (Dinophyceae) in NW Mediterranean coastal waters. Aquat Microb Ecol 46:55-70

> Green DH, Llewellyn LE, Negri AP, Blackburn SI, Bolch CJS (2004) Phylogenetic and functional diversity of the cultivable bacterial community associated with the paralytic shellfish poisoning dinoflagellate Gymnodinium catenatum. FEMS Microbiol Ecol 47:345-357

Guillard RRL, Hargraves PE (1993) Stichochrysis immobilis is a diatom, not a chrysophyte. Phycologia 32:234-236

Higman WA, Stone DM, Lewis JM (2001) Sequence comparisons of toxic and non-toxic Alexandrium tamarense (Dinophyceae) isolates from UK waters. Phycologia 40: 256-262

Ho AYT, Hsieh DPH, Qian PY (2006) Variations in paralytic shellfish toxin and homolog production in two strains of Alexandrium tamarense after antibiotic treatments. Aquat Microb Ecol 42:41-53

Hold GL, Smith EA, Birkbeck TH, Gallacher S (2001a) Comparison of paralytic shellfish toxin (PST) production by the dinoflagellates Alexandrium lusitanicum NEPCC 253 and Alexandrium tamarense NEPCC 407 in the presence and absence of bacteria. FEMS Microbiol Ecol 36:223-234

Hold GL, Smith EA, Rappe MS, Maas EW and others (2001b) Characterisation of bacterial communities associated with toxic and non-toxic dinoflagellates: Alexandrium spp. and Scrippsiella trochoidea. FEMS Microbiol Ecol 37:161-173

Ishida Y, Kim CH, Sako Y, Hirooka N, Uchida A (1993) PSP production is chromosome dependent in Alexandrium spp. In: Smayda TJ, Shimizu Y (eds) Toxic phytoplankton blooms in the sea. Elsevier, Amsterdam, p 881-887

- Ivars-Martinez E, D'Auria G, Rodriguez-Valera F, SanchezPorro C, Ventosa A, Joint I, Muhling M (2008) Biogeography of the ubiquitous marine bacterium Alteromonas macleodii determined by multilocus sequence analysis. Mol Ecol 17:4092-4106

Jasti S, Sieracki ME, Poulton NJ, Giewat MW, Rooney-Varga JN (2005) Phylogenetic diversity and specificity of bacteria closely associated with Alexandrium spp. and other phytoplankton. Appl Environ Microbiol 71:3483-3494

Kellmann R, Mihali TK, Jeon YJ, Pickford R, Pomati F, Neilan BA (2008) Biosynthetic intermediate analysis and functional homology reveal a saxitoxin gene cluster in Cyanobacteria. Appl Environ Microbiol 74:4044-4053

Kodama M, Ogata T, Sato S (1988) Bacterial production of saxitoxin. Agric Biol Chem 52:1075-1077
Kodama M, Ogata T, Sakamoto S, Sato S, Honda T, Miwatani $\mathrm{T}$ (1990) Production of paralytic shellfish toxins by a bacterium Moraxella sp. isolated from Protogonyaulax tamarensis. Toxicon 28:707-714

Kodama M, Doucette GJ, Green DH (2006) Relationships between bacteria and harmful algae. In: Granéli E, Turner JT (eds) Ecology of harmful algae, Ecological Studies Vol 189. Springer-Verlag, Berlin, p 243-255

Kopp M, Doucette GJ, Kodama M, Gerdts G, Schutt C, Medlin LK (1997) Phylogenetic analysis of selected toxic and non-toxic bacterial strains isolated from the toxic dinoflagellate Alexandrium tamarense. FEMS Microbiol Ecol 24:251-257

Lee SO, Kato J, Takiguchi N, Kuroda A, Ikeda T, Mitsutani A, Ohtake H (2000) Involvement of an extracellular protease in algicidal activity of the marine bacterium Pseudoalteromonas sp. strain A28. Appl Environ Microbiol 66: 4334-4339

Levasseur M, Monfort P, Doucette GJ, Michaud S (1996) Preliminary study of bacteria as PSP producers in the Gulf of St. Lawrence, Canada. In: Yasumoto T, Oshima Y, Fukuyo Y (eds) Harmful and toxic algal blooms. Intergovernmental Oceanographic Commission of UNESCO, Paris, p 363-366

> Lozupone C, Knight R (2005) UniFrac: a new phylogenetic method for comparing microbial communities. Appl Environ Microbiol 71:8228-8235

Ludwig W, Strunk O, Westram R, Richter L and others (2004) ARB: a software environment for sequence data. Nucleic Acids Res 32:1363-1371

- Martin AP (2002) Phylogenetic approaches for describing and comparing the diversity of microbial communities. Appl Environ Microbiol 68:3673-3682

Martins CA (2007) Functional genomics of a non-toxic Alexandrium lusitanicum culture. $\mathrm{PhD}$ thesis, Massachusetts Institute of Technology, Cambridge, MA

- Martins CA, Alvito P, Tavares MJ, Pereira P, Doucette G, Franca S (2003) Reevaluation of production of paralytic shellfish toxin by bacteria associated with dinoflagellates of the Portuguese coast. Appl Environ Microbiol 69: $5693-5698$

Martins CA, Kulis D, Franca S, Anderson DM (2004) The loss of PSP toxin production in a formerly toxic Alexandrium lusitanicum clone. Toxicon 43:195-205

Milowska K, Gabryelak T (2007) Reactive oxygen species and DNA damage after ultrasound exposure. Biomol Eng 24: 263-267

Moyer CL (2001) Molecular phylogeny: applications and implications for marine microbiology. In: Paul JH (ed) Marine microbiology: methods in microbiology, Vol 30. Academic Press, London, p 375-394

> Negri AP, Bolch C, Geier S, Green DH, Park TG, Blackburn SI (2007) Widespread presence of hydrophobic paralytic shellfish toxins in Gymnodinium catenatum. Harmful Algae 6:774-780

> Oshima Y, Bolch CJ, Hallegraeff G (1992) Toxin profiles of resting cysts of the dinoflagellate Alexandrium tamarense. Toxicon 30:1539-1544

Oshima Y, Blackburn SI, Hallegraeff GM (1993a) Comparative study on paralytic shellfish toxin profiles of the dinoflagellate Gymnodinium catenatum from three different countries. Mar Biol 116:471-476

Oshima Y, Buckley LJ, Alam M, Shimizu Y (1993b) Toxin production by the dinoflagellate Gymnodinium catenatum. In: Smayda TJ, Shimizu Y (eds) Toxic phytoplankton blooms in the sea. Elsevier, Amsterdam, p 907-912

Palacios L, Reguera B, Marin I (2006) Phylogenetic diversity of 
bacteria associated with toxic and non-toxic strains of Alexandrium minutum. Afr J Mar Sci 28:409-411

Pérez-Guzmán L, Pérez-Matos A, Rosado W, Tosteson T, Govind N (2008) Bacteria associated with toxic clonal cultures of the dinoflagellate Ostreopsis lenticularis. Mar Biotechnol 10:492-496

Plumley FG, Wei ZY, Toivanen TB, Doucette GJ, Franca S (1999) Tn5 mutagenesis of Pseudomonas stutzeri SF/PS, a bacterium associated with Alexandrium lusitanicum (Dinophyceae) and paralytic shellfish poisoning. J Phycol 35:1390-1396

Saitou N, Nei M (1987) The neighbour-joining method: a new method for reconstructing phylogenetic trees. Mol Biol Evol 4:406-425

Sako Y, Kim C, Ishida Y (1992) Mendelian inheritance of paralytic shellfish poisoning toxin in the marine dinoflagellate Alexandrium catenella. Biosci Biotechnol Biochem 56: 692-694

Sato S, Shimizu Y (1998) Purification of a fluorescent product from the bacterium Moraxella: a neosaxitoxin imposter. In: Reguera B, Blanco J, Fernández ML (eds) Harmful algae. Xunta de Galicia and Intergovernmental Oceanographic Commission of UNESCO, Grafisant, p 465-467

Sawayama S, Sako Y, Ishida Y (1993) New inhibitor for mating reaction of Alexandrium catenella produced by marine Alteromonas sp. Bull Jpn Soc Sci Fish 59:291-294

Schloss PD, Westcott SL, Ryabin T, Hall JR and others (2009) Introducing mothur: open-source, platform-independent, community-supported software for describing and comparing microbial communities. Appl Environ Microbiol 75: 7537-7541

Smith EA, Grant F, Ferguson CMJ, Gallacher S (2001) Biotransformations of paralytic shellfish toxins by bacteria isolated from bivalve molluscs. Appl Environ Microbiol 67: 2345-2353

Editorial responsibility: Ruben Sommaruga, Innsbruck, Austria
Smith EA, Mackintosh FH, Grant F, Gallacher S (2002) Sodium channel blocking (SCB) activity and transformation of paralytic shellfish toxins (PST) by dinoflagellateassociated bacteria. Aquat Microb Ecol 29:1-9

Subramanian TA (2007) Experimental models of bacteriaphytoplankton interactions and bacterial influence on growth of the toxic dinoflagellate, Gymnodinium catenatum. $\mathrm{PhD}$ dissertation, University of Tasmania, Launceston

Uribe P, Espejo RT (2003) Effect of associated bacteria on the growth and toxicity of Alexandrium catenella. Appl Environ Microbiol 69:659-662

- Wang Ch, Ho AYT, Qian Py, Wong Pk, Hsieh DPH (2004) Antibiotic treatment enhances $\mathrm{C} 2$ toxin production by Alexandrium tamarense in batch cultures. Harmful Algae 3:21-28

> Wang Q, Garrity GM, Tiedje JM, Cole JR (2007) Naive Bayesian classifier for rapid assignment of rRNA sequences into the new bacterial taxonomy. Appl Environ Microbiol 73:5261-5267

> Weisburg WG, Barns SM, Pelletier DA, Lane DJ (1991) 16S ribosomal DNA amplification for phylogenetic study. J Bacteriol 173:697-703

> Wichels A, Hummert C, Elbrachter M, Luckas B, Schutt C, Gerdts G (2004) Bacterial diversity in toxic Alexandrium tamarense blooms off the Orkney Isles and the Firth of Forth. Helgol Mar Res 58:93-103

> Wu-Scharf D, Jeong BR, Zhang C, Cerutti H (2000) Transgene and transposon silencing in Chlamydomonas reinhardtii by a DEAH-Box RNA helicase. Science 290:1159-1162

> Yutin N, Suzuki MT, Teeling H, Weber M, Venter JC, Rusch DB, Beja O (2007) Assessing diversity and biogeography of aerobic anoxygenic phototrophic bacteria in surface waters of the Atlantic and Pacific Oceans using the Global Ocean Sampling expedition metagenomes. Environ Microbiol 9:1464-1475

Submitted: December 11, 2009; Accepted: June 22, 2010

Proofs received from author(s): August 30, 2010 